\title{
ПРИРОДНЫЕ ФЕНОЛЫ И ИХ СИНТЕТИЧЕСКИЕ АНАЛОГИ КАК ФАРМАКОЛОГИЧЕСКИ АКТИВНЫЕ СУБСТАНЦИИ
}

\author{
А.В. Кучин, И.Ю. Чукичева \\ Институт химии Коми научного центра Уральского отделения \\ Российской академии наук, 167000, Россия, Сыктывкар, ул. Первомайская, 48. \\ DOI: 10.19163/MedChemRussia2021-2021-134 \\ E-mail:kutchin-av@mail.ru
}

Разнообразные встречающиеся в природе химические соединения могут быть получены с помощью относительно простых химических превращений [1]. В последние 15-20 лет использование таких методов, как рациональный дизайн лекарственных средств, комбинаторная химия и синтез библиотек соединений, оптимизация структуры лидеров и синтез аналогов природных соединений с заданной биологической активностью, исследование зависимости структура - активность и интенсивный скрининг новых соединений оказали большое влияние на разработки новых лекарственных средств [2]. Фармакофорные группы природных соединений широко представлены в списке «привилегированных структур», которые делают их идеальными кандидатами для построения активных блоков в химических библиотеках [3]. Замещенный фенол можно определить как структурную единицу многих биологически и фармакологически активных соединений.

В качестве структурных прототипов нами были выбраны природные фенольные соединения, в которых присутствует хиральный центр (пренилфенолы, терпенофенолы), фенилпропаноиды, кумарины, халконы и пр. [4]. Разработка на их основе гибридных структур или полифункциональных - многообещающее направление исследований при создании фармакологических субстанций [5].

В докладе будут продемонстрированы современные достижения в синтезе аналогов природных фенолов; перспективы их применения в качестве антиоксидантных, сердечно-сосудистых, противовирусных, противовоспалительных и радиопротекторных препаратов.

Работа частично выполнена при финансовой поддержке РФФИ (научный проект № 20-04-60493).

\section{Литература}

[1] J. Kim, H. Kim, S.B. Park. J. Am. Chem. Soc. 2014. 136, 42, 14629-14638.

[2] E.C. Barnes, R. Kumar, R.A. Davis. Nat. Prod. Rep. 2016. 33(3), 372-381.

[3] H. Sun, G. Tawa, Wallqvist. Drug Disc. Today. 2012.17, 310-324.

[4] S.A. Popova, O.G. Shevchenko et al., Chem. Biodiv. 2019, 16, е1800317; И.Ю. Чукичева, И.В. Федорова и др. ЖОХ. 2020. 90(3), 346-352; Попова С.А., Павлова Е.В., Чукичева И.Ю. Изв. АН. Сер. хим. 2020, 11, 2198-2204.

[5] E.V. Buravlev, O.G. Shevchenko, I.Y. Chukicheva, A.V. Kutchin, Chem. Pap. 2017, 1-8; M.A. Torlopov, O.G. Shevchenko, I.Yu. Chukicheva, E.V. Udoratina. React. \& Funct Polym. 2020.156, 104740. 